\title{
From homo economicus to homo corporativus: A neglected critique of neoclassical economics
}

\author{
Carlos Bastien, José Luís Cardoso* \\ ISEG, Technical University of Lisbon, Portugal
}

Accepted 21 November 2005

\begin{abstract}
In the 1930s, the conventional neoclassical concept of economic man was subject to different kinds of criticism. One contribution that so far has not been consistently scrutinised was presented by the economic doctrine of corporatism, which was particularly influential in Southern European countries. This paper deals with the foundations of the corporatist doctrine during the inter-war period, exploring the relevance of the concept of homo corporativus as a new approach to the study of economic behaviour and the economic representation of human nature.
\end{abstract}

(C) 2005 Elsevier Inc. All rights reserved.

JEL classification: A12; B20; B40; P40

Keywords: Homo economicus; Homo corporativus; Corporatism; Inter-war period; Economic behaviour; Heterodox economics

\section{Introduction}

The notion of rationalising economic agents is certainly one of the most important and powerful tenets of neoclassical economics. The idea has nevertheless met with strong disapproval from different schools of thought, as well as from single authors who do not directly oppose the course of mainstream orthodoxy. In general terms, it can be said that what these different critical views have in common is their rejection of the idea that human economic agency can be simply understood as the rational and calculating response of individuals to the opportunities and constraints of the

\footnotetext{
* Corresponding author at: ISEG, Technical University of Lisbon, Rua do Quelhas 6, 1200-781 Lisboa, Portugal. Tel.: +351213925 981; fax: +351213967309.

E-mail address: jcardoso@ iseg.utl.pt (J.L. Cardoso).
} 
market, given certain conditions and available resources. Another point of agreement is the need to consider an alternative explanation to rational choice theory, one that takes into account the role of ethical principles, social norms and institutions in the construction of human action.

Among the opponents of neoclassical economics, attention should be paid to the criticisms developed by the supporters of corporatism, the doctrine which, during the inter-war period, was successfully received and widely acclaimed in Southern European countries, namely Italy and Portugal. According to this doctrine, which is closely linked to the political validation of authoritarian, fascist-like regimes, individual economic agents are not moved primarily by rational, individual motivations, but by natural instincts of cooperation and association. The coordination of individual actions is made possible through institutional supervision and control guaranteed by the corporations and the State. The latter is credited with the special role of interpreting the will of the entire nation.

This paper seeks to present the main ideas about economic behaviour and agency put forward by both the enthusiastic and the more moderate advocates of corporatism in Portugal and Italy during the inter-war period. ${ }^{1}$ Our attention will be specially directed towards the work produced by Portuguese authors, bearing in mind the influence inherited from those Italian corporatist authors who pioneered the development of this distinct doctrinal framework. Such a choice is based on the relative neglect afforded to the question of the relevance and originality of the literature on corporatism produced in both countries.

The focus on Portugal helps to better identify a special case study, while allowing for inferences that may apply to other cases. It is not our aim to draw general conclusions from this particular historical experience, but rather to take it as an illustration of the development of economic thought in the inter-war years, in a way that both conveys the general economic culture of the period and enlightens problems that might also have occurred elsewhere.

Indeed, the scope of the topic under discussion goes far beyond its original, fairly limited geographical and ideological frontiers. It should be noted that the emergence of corporatism occurred at a time when important steps were being taken to structure the homo economicus paradigm (Robbins, 1932). It was also the period when Keynes put forward the strongest possible arguments against the model of a self-regulating economy based on the rational behaviour of economic agents (Keynes, 1936). We therefore argue that the efforts made to build a corporatist economic doctrine shed new light upon our historical understanding of the context associated with the formation of, divergence from, and opposition to, mainstream neoclassical economics in this period. We also claim that the critique of the concept of human nature embodied in the notion of homo economicus is the key methodological element explaining this divergence and opposition. The paper begins with a summary of the state of economic thought in Portugal on the threshold of the corporatist era (Section 1). Though necessarily brief, this section provides a basic historical contextualisation of the emergence of corporatism. After this, the main theoretical arguments made available by the advocates of this school of thought in their attempts to overcome the conventional notion of homo economicus are briefly presented (Section 2). We then move on to a more detailed discussion of the role played by a different notion of economic agent, according to which the relevant features of human nature and social order are not those usually associated

\footnotetext{
${ }^{1}$ The analysis could also be extended to Spain, though the more limited scope of the corporatist movement in this country and its closer association to the development of technical arguments in favour of economic regulation by the State. Spanish historiography still shows some reluctance in admitting the identity of a pure corporatist ideology in Spain over that period, as shown by the absence of any autonomous account of corporatist economic doctrines in the most recent and complete book on the history of economic thought edited in Spain (Quintana, 2001).
} 
with the concept of homo economicus, but rather a set of different motivations defining the very nature of homo corporativus (Section 3). The paper ends with some concluding remarks.

\section{The attempts to build a corporatist economic theory}

In most European countries, the inter-war period brought an evident change in social and political structures, as well as an increasing rejection of liberal ideas. This was also a consequence of the Great Depression, which led to new economic strategies and policies, an increase in state economic interventionism, criticism of the prevailing neoclassical paradigm, and a tentative formulation of alternative or "corrective" ideas to that paradigm, either adapting them or replacing them with other theoretical approaches, seemingly better suited to the particularities of national environments.

In this context, Portugal is a case-study that merits greater research, not only because of the originality of the contributions offered, but also because of the lesser attention paid to it in comparison with the Italian case. The institutionalisation of the Estado Novo (New State) in Portugal in 1933 - achieved through the approval of a coherent set of programmatic documents that were to serve as guidelines for economic, social and political life - respected the essence of corporatism. This ideology was based on the subjection of the individual to the superior interests of the nation, collaboration between classes, and acceptance of the idea that the semi-autonomous bodies representing the various branches of economic and social activity should be given formal powers in defining public policies, in order to fulfil the main objective of attaining social harmony and political stability (see Caetano, 1938).

One of the main doctrinal implications of this view is that class and other social conflicts cannot be regarded as the natural foundation of society, which is instead based on cooperation and social integration arising from functional and vocational groupings. Another important issue associated with this conceptual framework is the rejection of a notion of liberal politics based exclusively on a system of parties and universal suffrage. Indeed, special emphasis is given to the moral dimensions of man and social life, in keeping with the basic idea that an organic social whole is opposed to the notion of a mere sum of utility-maximising individuals. The way in which Portugal accompanied this change in the nature of ideas was constrained to some extent by economic backwardness, the country's unsteady progress in the training of economists and the organisation of economic research, and the predominance of doctrinal debate over theory, as well as the fact that modern neoclassical economics had been introduced only very belatedly and superficially. In contrast to what happened in other European countries - namely Italy pre-Marshallian, Marshallian and Walrasian economic theories never played an important part in the formation of mainstream economic thought in Portugal. Moreover, the various schools that developed criticisms and alternative approaches to the marginalist and neoclassical traditions in economics - namely Marxism, institutionalism, Schumpeterianism, the theory of monopolistic competition and Keynesianism - also tended to be afforded only limited expression in the country.

Despite this limitation, some Portuguese economists of this period showed themselves to be fairly receptive to the theoretical innovations being produced in both European and American academic circles. Among these authors, special mention should be made of Leite (1933) and Ribeiro (1934), who dealt respectively with business cycle theory and monopolistic and imperfect competition. But these two academic dissertations were the exceptions, thus confirming that the most important theoretical contributions of this period of "high theory" did not deserve any comment or discussion and went largely unnoticed in Portugal. The path leading to a more theoretical approach was impeded by the specific situation of the Portuguese economy and society. The corporatist 
Constitution of 1933, the enforcement of a political dictatorship, the apparent loss of the university's autonomy, and the voluntary adherence and attraction of some economists to Salazar's blueprint (Salazar, 1933), implied that the main feature of the Portuguese economic landscape, especially after 1934-1935, consisted of the setting up of a corporatist doctrine as an alternative to the internationally prevailing neoclassical orthodoxy. A clear demonstration of this trait is provided by the shift in Leite and Ribeiro's own academic careers. The two most promising economic theorists in the early 1930s soon became two of the main mentors of the corporatist doctrine.

In the design and development of the corporatist programme in Portugal, a crucial role was played by the influences originating from Italy, both with regard to the models of legislation adopted (such as, for example, the adaptation made of the Carta del Lavoro into the Portuguese Estatuto do Trabalho National, National Labour Charter) and in terms of the readings that served as the source of inspiration for theoretical and doctrinal innovation.

These efforts were not to last long, however. By the end of World War II, when the vast majority of the European fascist-type regimes were defeated, the research centre of the Law Faculty of Coimbra, where the most sizeable group of Portuguese corporatist economists were gathered, was also disbanded.

Deprived of the regular flow of ideas produced by the Italian fascist economists (some of them, such as Alberto Bertolino, Bruno Biaggi or Ugo Spirito, lectured in Portugal or had their books translated into Portuguese), the corporatist economic project remained an unfinished and sometimes quite ambiguous theoretical corpus. From a doctrinal standpoint, corporatism would continue to survive, based upon existing labour relations arrangements and a long-lasting national reticence as to the benefits to be expected from a fully fledged market economy. And it served quite well as an instrument for the doctrinal and political legitimisation of the regime. But, in the attempts to establish it as a body of economic theory, corporatism was only to survive as a minor auxiliary subject in the teaching of corporatist law. After World War II, economic regulation by the state was no longer based on the ideology of corporatism, but rather on authoritarian and protectionist instruments to promote industrial growth.

\section{Breaking away from homo economicus}

The new economic system was based on moral, religious and historical principles, but it still called out for some form of scientific legitimisation. Economists were therefore expected to provide a rationale for the ongoing corporatist experience, namely for the economic strategy of maintaining the economic and social equilibrium that would prevail in Portugal until the end of World War II. Their basic assumption was that the new corporatist system would be conceived of as an alternative to both capitalism and socialism. They therefore tried to construct an economic theory of a third system, one that avoided both the evils of the socialist planned economies (the lack of individual freedom) and the social errors inherent in the system of liberal capitalism (extreme competition, poverty, a waste of resources).

It should be noted that this attempt was also shared by many other schools of thought and authors who insisted on the merits of a "third way" while maintaining a certain critical distance in relation to the loss of political freedom and individual rights that had proved to be a typical feature of fascist or similar regimes. The corporatist experiments were therefore positively assessed by those who believed that the class struggle was not an inherent condition in capitalist economic and social organisation - in relation to either the ownership of the means of production or the distribution of income - i.e. by those who assumed that collaboration and harmony between capital and labour was the driving force behind any developed economy and society. 
Among the more basic concepts of classical and neoclassical economics, the doctrinaire supporters of corporatism explicitly questioned the invisible hand and other economic concepts related to the notion of natural equilibrium, such as market price and market wage. Their attention was instead directed towards explaining the functioning of the visible hand of both the State and the corporations, as well as towards determining the corporatist price and the corporatist wage. They also tried to construct a new theory of distribution.

In spite of their common aims, there were, however, some important differences in their approaches to the workings of the would-be new economic system.

Some of the economists who had closer links with the neoclassical tradition took for granted a soft version of the homo economicus, i.e. an economic agent who is 'self-interested, rational, unchanging, separate, and unreflective' (Tomer, 2001, pp. 281-182). The defenders of this vision saw the homo economicus as a fundamental tool for economic analysis, although they also considered the State and the corporatist bureaucracy as the necessary and appropriate institutions for regulating the economy and prevailing over the shortcomings that would inevitably arise from the behaviour of individual economic agents with a limited sense of the common good.

In this sense, it was claimed that one could not ignore "the complex scientific elaborations in the field of economics, from the classical school to the present time" (Leite, 1936, p. 90), implying that, after all, corporatism was nothing more than a "doctrine that acknowledges the need to restrict or moderate the economic factors and impulses" (Leite, 1936, p. 61), as well as a "a current of economic policy" (Leite, 1936, p. 89). A few years later, another author, while acknowledging that "there is no reason to exclude from economic analysis the actions determined by impulses other than selfish motivation" (Veiga, 1941, p. 40), clearly repudiated the radical orientation expressed by some of the Italian corporatists, who sought to reconstruct economics with totally different assumptions. Veiga simply recommended the renewal of traditional economic theory "through the indispensable corrections and additions, in order to take into account the changes that have occurred in the economic system" (Veiga, 1941, pp. 92-93).

According to these economists, selfish private interests could be accepted as being at the very heart of the corporatist system, and thereby affording the necessary stimuli for economic progress, provided that the corporatist organisations controlled the natural propensity of individuals to satisfy their interests within the limits of the achievement of the common good. However, this kind of corporatist control was quite different from other, non-authoritarian approaches, that aimed at reconciling individual interests in a broader welfare context.

They therefore saw market competition as a useful means of resource allocation, provided that it was in fact assisted and, at the same time, limited by certain State and corporatist regulations. The goal was to reach a kind of general social equilibrium and a Pareto optimum-a common welfare, in their words. However, instead of accepting the market system as an efficient self-regulating mechanism, they thought that some kind of intervention was required to prevent economic fluctuations, crises and various different types of social waste (Leite, 1936).

In much the same way as the first neoclassical synthesis - which corporatism sought to replace even though it ended up using some of the same reasoning but achieving different conclusions - the corporatist doctrinaires were confined to a static approach and did not produce any kind of dynamic economics or growth theory. In a long-run perspective, they only admitted the transformation of capitalism into a vaguely defined corporatist economy. As far as international economics was concerned, they reduced nationalism to a somewhat vague support of protectionism, bearing a slight resemblance to Manoilescu's (1929) doctrines.

These views show important influences and similarities to one of the main currents of thought to be found amongst Italian authors, namely the strand represented by Luigi Einaudi. According to 
this economist, it would be possible to fit the corporatist project within the broader framework of the market economy, the State being endowed with the mission of ensuring moderation and equilibrium, which could not be spontaneously accomplished through the system of free competition. Preventing the formation of trusts and cartels, supervising undesirable monopolistic practices, creating instruments to foster and regulate competition between economic agents-these were the purposes he considered most advisable and respectable. Even more important than Einaudi's reforming proposals of a moderate liberal nature was his epistemological attitude consisting of the acceptance of the principle that "the categories of traditional economic analysis were not only kept intact, but they were in fact necessary to classify and comprehend the phenomena of the corporatist economy" (Faucci, 1990, p. 15).

In both countries, a wise use was made of certain analytical tools provided by mainstream neoclassical economics, in order to explain the problems arising from the actual functioning of the corporatist economic system. Neoclassical orthodox theory could even be accepted or tolerated, provided that the most negative attributes of the homo economicus were eradicated from economic discourse.

\section{In search of a new definition of human nature: the homo corporativus}

The compromising attitude defended by the authors discussed in the previous section was, however, far from being fully endorsed. A different approach was followed in Italy by some economists such as Gino Arias, Filippo Carli, Massimo Fovel and, above all, Ugo Spirito, according to whom corporatism represented not only a new economic and social order but also a new scientific device for explaining economic life (cf. Cavalieri, 1994). His main arguments were based on a severe criticism of the notion of homo economicus, by defending the principle that there is a perfect identity between the individual and the State. This is a basic philosophical principle - quite different from the logical positivism and individualism embedded in mainstream neoclassical economics - according to which the fulfilment of self-interest can only be reached through the implementation of national interest, a kind of general will faithfully interpreted by the State (cf. Perri and Pesciarelli, 1990).

The similarity with the situation experienced in Portugal could hardly be greater, despite the lesser degree of theoretical reasoning and the nearly complete absence of the tradition of marginalism and of the so-called pure economics in Portugal. In both countries, there were attempts to create an alternative economic theory, whose most important characteristics were the rejection of both the sterile and artificial nature of abstract mathematical reasoning and the use of the homo economicus as a main analytical tool. Ugo Spirito, whose work was translated into Portuguese only a year after its original publication (Spirito, 1934), was particularly influential in this country. As was explicitly recognised by Teixeira Ribeiro, it was not surprising that there should be such frequent recourse to these Italian authors, "for it is in Italy - as everyone knows - that the economic theory of corporatism has been subjected to the broadest and most profound study so far" (Ribeiro, 1939, p. 3).

Spirito's influence was to be particularly noted in the criticism that was made of neoclassical economic theory and its presuppositions of free competition, the spontaneous equilibrium of markets and the absence of state interventionism. One additional reason to acclaim Spirito was his strong rejection of the use of abstract reasoning and mathematical instruments in economics.

The development of the new notion of homo corporativus proved to be particularly challenging. The homo corporativus is different from the homo economicus, not only because he is a social being oriented towards belonging to communities, but also because he is directed by a notion 
of social interest provided by both the corporations and the State. He is recognised as having a changing character and a non-separate nature, since he is strongly influenced by idealistic values and moral considerations. This construction is part of a broader approach to the process of socialisation - with the inherent notion of homo sociologicus - that explains how norms are internalised and so come to motivate individuals. This means that it is no longer enough to believe in the virtues of selfish behaviour and self-interest in order to explain what prompts rational agents to action. The claim that social life is the interplay of rational individuals (cf. Hollis, 1987) needs to be complemented with the idea that there are social norms shared and sustained by different people in a given society, which help to make it clear that individual rational behaviour is the expression of the self in a social world and that it also generates coordination, cooperation and social harmony (cf. Elster, 1989). In this sense, we may say that the corporatist movement plays its role in changing the atomistic conception of individual behaviour that characterises neoclassical economics as part of a broader view of individuals as socially embedded (cf. Davis, 2003). ${ }^{2}$

As far as the doctrine of corporatism is concerned, the notion of self-interest is replaced by the notion of a common national concern. The device of instrumental rationality is now conceived in a broader institutional context, where individuals are seen as acting within the framework of corporations. The ability to choose and decide according to the rules of the utility calculus are also tempered by the superior notion of social welfare. Such was the new fate, the integrated destiny, of the homo corporativus.

Some Portuguese corporatist writers considered that "in our theoretical conceptions, we should oppose the homo corporativus to the homo economicus" (Leite, 1935, pp. 1-2) or furthermore that "the corporatist economy does not start from selfishness: the homo corporativus does not aim anymore at the mere private utility, because he is made of the spirit of cooperation and sociability" (Ribeiro, 1938, pp. 96-97).

However, the problem of the legitimacy of a scientific inquiry guided by the concept of homo corporativus still had to be solved. Most Portuguese corporatist authors admitted that corporatism as a social and economic system was not feasible in the short term and could hardly be implemented in the long term, since it would be difficult to achieve convergence between the individual interests looked after by the homo corporativus and the general social interest. As Ribeiro recognised, the legitimacy of such a version of the corporatist theory was disturbed by the fact that its starting point "was nothing more than the point of arrival of the corporatist organisation" (Ribeiro, 1938, p. 112).

Anyway, most corporatist economists admitted that it was indeed quite difficult to achieve such a radical change in human nature (notwithstanding the intensive propaganda in favour of such a change) which would lead all individuals to sacrifice their particular interests for the benefit of the common good. The idea of a man rejecting the hedonistic principle and driving his own particular interests along the path of an affectio societatis, in order to make them coincide with the common welfare, was seen as unrealistic and therefore unlikely to represent human reality or to serve as the basis for any robust theoretical construction.

Even Antonio Salazar, a professor of economics and the leader of the Portuguese corporatist state, could not prevent himself from attacking the concept of homo economicus in his academic lectures, considering it to be "an abstract and artificial conception" (Salazar, 1927, p. 57). Nevertheless, in order to replace it, he advocated the development of an inductive and descriptive form

\footnotetext{
${ }^{2}$ It should also be noted that the very first use of the notion of homo economicus, which dates back to the work of John Stuart Mill, highlights this institutional and sociological nature of man's behaviour and establishes the context for his actions and motivations (cf. Persky, 1995).
} 
of economics, not a new abstract theory based on the concept of homo corporativus. His vision of the reform of the economic system - namely the limits to be imposed on selfishness and free competition - was mainly directed towards the defence of an authoritarian State interventionism defined as "halfway between individualism and socialism" (Salazar, 1927, p. 409), thus devaluing the role of corporations and showing a weak belief in the ability of corporatist self-regulation to promote social equilibrium.

These difficulties lay at the origin of the above-mentioned parallel attempt to develop a theory of corporatism that could accommodate the notion of homo economicus, given that the unrealistic assumptions on which this notion was grounded were not overcome by the equally unrealistic and inconsistent hypotheses of a new economic agent, the so-called homo corporativus.

The obvious difficulty in constructing an original body of corporatist theory becomes evident when we observe that in none of the textbooks on corporatist economics published during this period was any attempt made to elaborate a theory based on the notion of homo corporativus. The hesitation and ambiguity shown in dealing with basic doctrinal issues also led to a different attempt to define a theoretical third way. Its supporters reduced the importance of individual rationality to a minimum and sought to regard social groups and collective organisations as the most important analytical basis for their theoretical and doctrinal constructions.

As staunch opponents of laissez-faire, some of the ideologists of corporatism extolled the notion of a self-directed economy, which did, however, have nothing to do with the mechanisms leading to the spontaneous equilibrium of the market that were so much to the liking of neoclassical economics. The following excerpt from Teixeira Ribeiro clearly illustrates this distinction:

"Corporations therefore collaborate in the performance of a normative role. And this is why the activities of individuals and companies are now subjected to a form of discipline or, better still, are conditioned by certain initial positions that are implied by this discipline.

We are far removed from automatic equilibrium: instead of this, we have a directed economy. But, in this case, such control does not belong directly to the state, for it is the industries that, through their corporation, take the initiative of drawing up the rules and regulations. Afterwards, it is the task of the government, as the representative of the national interest, to decide upon these rules in the last instance, either approving them or rejecting them. Now, since the industries collaborate in their own discipline, it is said that we have instead a self-directed economy" (1939: 61-62).

In Ribeiro's opinion, in a fully corporatist economy, corporations should regulate economic activity by means of a complex system of bilateral monopoly markets. The self-directed economy thus presupposed a high degree of state intervention when the corporatist organisation was first founded, which thereafter would be followed by a gradual decline in such protagonism.

The incentive for the creation of corporations embodied a logic of social and economic organisation in which the realisation of the general interest was previously measured by harmonising the interests of the different agents and groups of agents operating in a market overseen by the state. The fixing of prices, the entry of new firms into the market, the regulation of working conditions, the determination of wage levels, the analysis of production costs and, generally speaking, all operations that involved the use of economic calculation, which, under a system of free competition, represent elementary procedures in the choices that can be made within the context of a scarcity of available resources - i.e. the typical framework for the decision-making of the homo economicus enshrined in the neoclassical economic literature - all these features would be the privileged area for the corporations and the employers' federative organisations (guilds) to 
decide upon. The guilds would afford corporations greater national representativity and, above all, provide a horizontal control of the activities associated with a particular product (wheat, rice, olive-oil, wool, wine, just to mention the main ones).

\section{Concluding remarks}

Corporatism aimed at becoming a respectful doctrine dealing with the defence of a controlled organisation of individual interests in contrast to the unconditional acceptance of the search for self-interest. By giving primacy to the ideals of cooperation and solidarity, it made it difficult to accept the idea that the market operates according to a self-regulatory system of free competition. Our main purpose in this article has been to assess the potential and the shortcomings of the conception of homo corporativus, in the light of the historical development of economics during the inter-war period. It goes without saying that this criticism of the conventional neoclassical doctrine of homo economicus was only one among a range of other critical, heterodox approaches to economic man and the definition of human economic nature. ${ }^{3}$

We arrive at the conclusion that the efforts to create an original corporatist economic theory were somehow frustrated. Despite being strongly opposed and subject to severe criticism, the homo economicus was able to resist the assault of the homo corporativus. Nevertheless, the fact that those endeavours did not give rise to a coherent body of assumptions and principles does not imply that they were totally irrelevant. In the context of the social, economic and political situation experienced in Portugal, especially during the inter-war period, the opposition to the notion of rational, optimising economic agents seeking to achieve their own private interests proved to be a guiding force which brought a new raison d'etre to legitimise the existing institutions and policies of the Estado Novo and its underlying principle of social equilibrium and harmony.

Notwithstanding this sincere wish to build up an alternative to the prevailing orthodox notion of homo economicus, it should be emphasized that such intellectual efforts came from people too much committed with the legitimisation of the authoritarian political regime, either in Portugal or in Italy. This represented a major shortcoming of the corporatist movement, as its main supporters were a kind of organic intellectuals, faithful contributors to the strengthening of the regime, even though this was not a component of their original intentions.

The historical relevance of corporatism is, therefore, closely linked to its capacity to serve a political agenda, in the context of the distress and discomfort felt by those who tried simultaneously to oppose the two economic systems prevalent during the inter-war period: liberal capitalism and planned socialism.

\section{Acknowledgements}

We are grateful to Philippe Fontaine, Eyup Ozveren, John Tomer and an anonymous referee of this journal for their helpful comments. The usual disclaimer applies.

\section{References}

Caetano, M., 1938. O Sistema Corporativo. Jornal do Comércio e das Colónias, Lisboa.

\footnotetext{
${ }^{3}$ We have deliberately omitted any discussion of those different heterodox views, based on institutional, humanistic and social concerns (cf. Tomer, 2001).
} 
Cavalieri, D., 1994. II corporativismo nella storia del pensiero economico italiano: una rilettura critica. II Pensiero Economico Italiano 2 (2), 7-49.

Davis, J.B., 2003. The Theory of the Individual in Economics. Identity and Value. Routledge, London.

Elster, J., 1989. The Cement of Society. A Study of Social Order. Cambridge University Press, Cambridge.

Faucci, R., 1990. Un'epoca di transizioni? Le coordinate teorico-istituzionali del periodo. Quaderni di Storia dell'Economia Politica 8 (2/3), 3-22.

Hollis, M., 1987. The Cunning of Reason. Cambridge University Press, Cambridge.

Keynes, J.M., 1936. The General Theory of Employment, Interest and Money. Macmillan, London.

Leite, J.C., 1933. Ensaio sobre a Teoria das Crises Económicas. Coimbra Editora, Coimbra.

Leite, J.C., 1935. A doutrina corporativa e a teoria económica. Boletim do Instituto Nacional do Trabalho e Previdência 2 (6), 131-136.

Leite, J.C., 1936. A Doutrina Corporativa em Portugal. Livraria Clássica Editora, Lisboa.

Manoilescu, M., 1929. La Théorie du Protectionnisme et de l'Echange International. M. Giard, Paris.

Perri, S., Pesciarelli, E., 1990. II carattere della scienza economica secondo Ugo Spirito. Quaderni di Storia dell'Economia Politica 8 (2/3), 415-458.

Persky, J., 1995. The ethology of homo economicus. Journal of Economic Perspectives 9 (2), 221-231.

Quintana, E.F., 2001. Economia y Economistas Españoles, vol. 6: La modernización de los estudios de economia. Galaxia Gutenberg, Barcelona.

Ribeiro, J.T., 1934. Teoria Económica dos Monopólios. Coimbra Editora, Coimbra.

Ribeiro, J.T., 1938. Lições de Direito Corporativo. Coimbra Editora, Coimbra.

Ribeiro, J.T., 1939. Princípios e Fins do Sistema Corporativo Português. Coimbra Editora, Coimbra.

Robbins, L., 1932. An Essay on the Nature and Significance of Economic Science. Macmillan, London.

Salazar, A.O., 1927. Economia Politica. Gráfica Conimbricense, Coimbra.

Salazar, A.O., 1933. Conceitos Económicos e Sociais da Nova Constituição. Tip. Gazeta dos Caminhos de Ferro, Lisboa. Spirito, U., 1934. Princípios Fundamentais de Economia Corporativa. Livraria Civilização, Lisboa.

Tomer, J.F., 2001. Economic man vs. heterodox men: the concepts of human nature in schools of economic thought. Journal of Socio-Economics 30 (4), 281-293.

Veiga, A.M., 1941. A Economia Corporativa e o Problema dos Preços. Universidade de Lisboa, Lisboa. 